EKONOMIKAWAN : Jurnal Ilmu Ekonomi dan Studi Pembangunan

ISSN : $1693-7600$ (Print), ISSN : 2598-0157 (Online), http://jurnal.umsu.ac.ld/index.php/ekawan

\title{
Analisis Elastisitas Investasi Dengan Penurunan Kemiskinan Provinsi Kalimantan Selatan Tahun 2010-2017
}

\author{
Arif Maulana \\ Badan Pusat Statistik Kabupaten Hulu Sungai Tengah, Kalimantan Selatan, Indonesia \\ Jl. Keramat Manjang No. 10 Barabai 71313 \\ e-mail : maulana127041@gmail.com
}

\begin{abstract}
ABSTRAK
Kemiskinan merupakan permasalahan serius yang harus diatasi negara berkembang. Pemerintah sangat berperan penting dalam menanggulangi masalah kemiskinan. Pemerintah melalui Nawa Cita menjadikan investasi berupa pembangunan infrastruktur yang menjadi program unggulan. Pembangunan infrastruktur ditujukan untuk mempercepat pertumbuhan ekonomi yang akan menurunkan kemiskinan dan meningkatkan kesejahteraan. Penelitian ini bertujuan untuk menganalisis apakah investasi atau pembangunan infrastruktur yang gencar dilakukan oleh Pemerintah saat ini efektif dan efisien dalam menurunkan angka kemiskinan di Kalimantan Selatan. Penelitian ini dilakukan dengan pendekatan kuantitatif deskriptif dengan menggunakan data persentase penduduk miskin dan Produk Domestik Regional Bruto (PDRB). Alat analisis yang digunakan adalah rumus elastisitas. Berdasarkan hasil penghitungan menggunakan rumus elastisitas, gencarnya pembangunan infrastruktur berhasil menurunkan tingkat kemiskinan selama tahun 2010-2017. Investasi yang digelontorkan sebelum maupun sesudah 2014 sudah on the track, karena sama-sama memberikan nilai elastisitas negatif terhadap kemiskinan. Akan tetapi, jika dilihat dari besaran elastisitasnya, setelah tahun 2014 nilai elastisitasnya lebih kecil dibanding periode sebelumnya. Hal ini menunjukkan investasi yang dilakukan kurang efisien dalam menurunkan angka kemiskinan di Kalimantan Selatan.
\end{abstract}

Kata kunci: infrastruktur, negara berkembang, angka kemiskinan, elastisitas, PDRB 


\title{
Analysis of Investment Elasticity by Decreasing Poverty South Kalimantan Province in 2010-2017
}

\begin{abstract}
Poverty is a serious problem that must be overcome by developing countries. The government plays an important role in overcoming the problem of poverty. The government through Nawa Cita made investment in the form of infrastructure development which became the main program. Infrastructure development is aimed at accelerating economic growth which will reduce poverty and improve welfare. The purpose of this study is to analyze whether investment or infrastructure development that is intensively carried out by the Government is currently effective and efficient in reducing poverty in South Kalimantan. This research was conducted with a descriptive quantitative approach using data poverty rate and Gross Regional Domestic Product $(G R D P)$. The analysis tool used is the formula for elasticity. Based on the results using the elasticity formula, the development of infrastructure has succeeded in reducing poverty rate during 2010-2017. Investments made before and after 2014 have been on the track, because provide negative elasticity values for poverty rate. However, reviewed from the amount of elasticity, after 2014 the value of elasticity is smaller than the previous period. This shows that investments made are less efficient in reducing the poverty rate in South Kalimantan.
\end{abstract}

Keywords: infrastructure, developing countries, poverty rate, elasticity, GRDP

\section{PENDAHULUAN}

"Kemiskinan merupakan permasalahan sosial yang selalu ada pada masyarakat, khususnya di negara berkembang" (Kolibu, Rumate, \& Engka, 2017). "Ada berbagai faktor penyebab kemiskinan, yaitu tingkat investasi masih dibawah standar, lambatnya pertumbuhan ekonomi, dan belum efektifnya pengeluaran pemerintah pada program yang efektif dalam menurunkan angka kemiskinan" (Pateda, Masinambouw, \& Rotinsulu, 2017).

Kemiskinan diartikan sebagai ketidakmampuan seseorang atau sekelompok orang dalam mencukupi tingkat kemakmuran ekonomi yang merupakan kebutuhan minimal dari standar hidup tertentu. Kemiskinan dipahami sebagai keadaan kekurangan uang maupun barang untuk menjamin kelangsungan hidup (Paramita \& Purbadharmaja, 2015). Sedangkan menurut Mahsunah (2013), kemiskinan terjadi ketika seseorang tidak mampu untuk memenuhi berbagai macam kebutuhan seperti sandang, papan, pangan, pendidikan, kesehatan, dan sebagainya. 
Published July 2019

EKONOMIKAWAN : Jurnal Ilmu Ekonomi dan Studi Pembangunan

ISSN : $1693-7600$ (Print), ISSN : 2598-0157 (Online), http://jurnal.umsu.ac.Id/index.php/ekawan

Ada banyak definisi tentang kemiskinan di Indonesia, namun yang hingga saat ini diterapkan oleh Badan Pusat Statistik (BPS), kemiskinan dipandang sebagai ketidakmampuan ekonomi dalam memenuhi kebutuhan dasar yang berupa makanan dan bukan makanan, diukur dari sisi pengeluaran. Menurut BPS, penduduk dikategorikan miskin apabila mempunyai rata-rata pengeluaran perkapita perbulan di bawah garis kemiskinan. Garis kemiskinan merupakan besaran nilai rupiah yang dibutuhkan oleh penduduk daerah tertentu dalam memenuhi kebutuhan pokok makanan dan bukan makanan. Garis kemiskinan bersifat relatif dan berubah setiap periodenya. Setiap provinsi di Indonesia memiliki garis kemiskinan yang berbeda. Garis kemiskinan Provinsi Kalimantan Selatan dapat dilihat pada gambar di bawah ini:

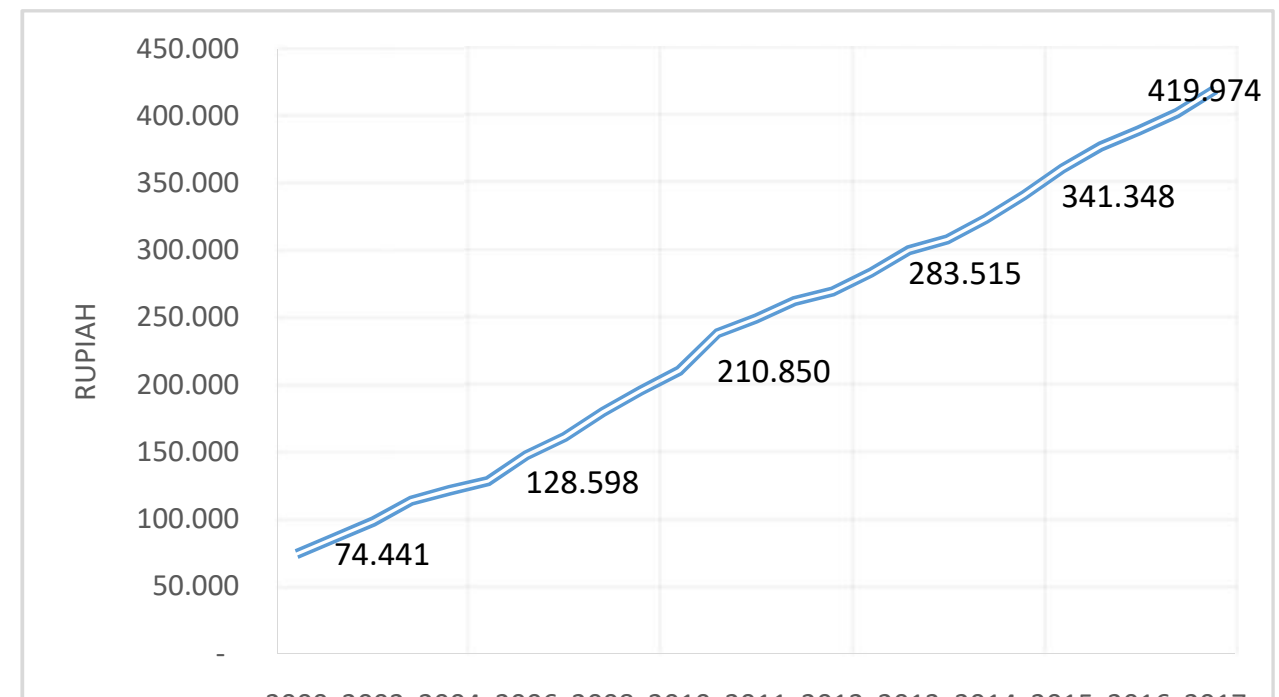

2000200220042006200820102011201220132014201520162017

Gambar 1. Perkembangan Garis Kemiskinan Provinsi Kalimantan Selatan Tahun 2000-2017 (https://kalsel.bps.go.id/)

Garis kemiskinan Provinsi Kalimantan Selatan mengalami peningkatan dari tahun 2000 ke tahun 2017. Pada September tahun 2017 angka ini mencapai Rp 419.974,-perkapita perbulan. Seorang penduduk dengan pengeluaran perbulan kurang dari Rp 419.974,- akan dikategorikan sebagai penduduk miskin menurut konsep ini. Semua penduduk yang pengeluarannya di bawah garis kemiskinan diagregasi menjadi jumlah penduduk miskin.

Berdasarkan data BPS, hingga tahun 2017 masih terdapat 194 ribu penduduk miskin atau sekitar $4,70 \%$ dari seluruh penduduk Kalimantan Selatan. Program-program pembangunan yang sudah berjalan hingga saat ini masih menyisakan sejumlah penduduk dengan taraf hidup di bawah garis kemiskinan. Berbagai program pemerintah sudah digelontorkan untuk menangani masalah kemiskinan, di antaranya adalah Program Indonesia Pintar (PIP), Kartu Keluarga Sejahtera/Kartu Perlindungan Sosial (KKS/KPS), Kredit Usaha Rakyat (KUR), dan Beras miskin (Raskin). Sebanyak 6,03\% rumah tangga Kalimantan Selatan menyatakan menerima bantuan PIP, KKS/KPS 9,05\%, Raskin 18,82\%, dan KUR 24,75\%. Akan tetapi, sampai sekarang kemiskinan masih menjadi masalah yang tidak kunjung selesai. 


\section{Published July 2019}

\section{EKONOMIKAWAN : Jurnal Ilmu Ekonomi dan Studi Pembangunan}

ISSN : 1693-7600 (Print), ISSN : 2598-0157 (Online), http://jurnal.umsu.ac.Id/index.php/ekawan

Di samping masalah kemiskinan, satu hal lagi yang perlu diwaspadai adalah masalah ketimpangan. Ketimpangan ditengarai menjadi biang keladi atau akar dari masalah kemiskinan. Salah satu tools yang dapat digunakan untuk mengukur ketimpangan adalah Gini rasio yang merepresentasikan besaran angka dari nol sampai satu, semakin tinggi nilainya artinya semakin timpang. Berikut adalah gambaran indikator kemiskinan dan ketimpangan di Kalimantan Selatan.

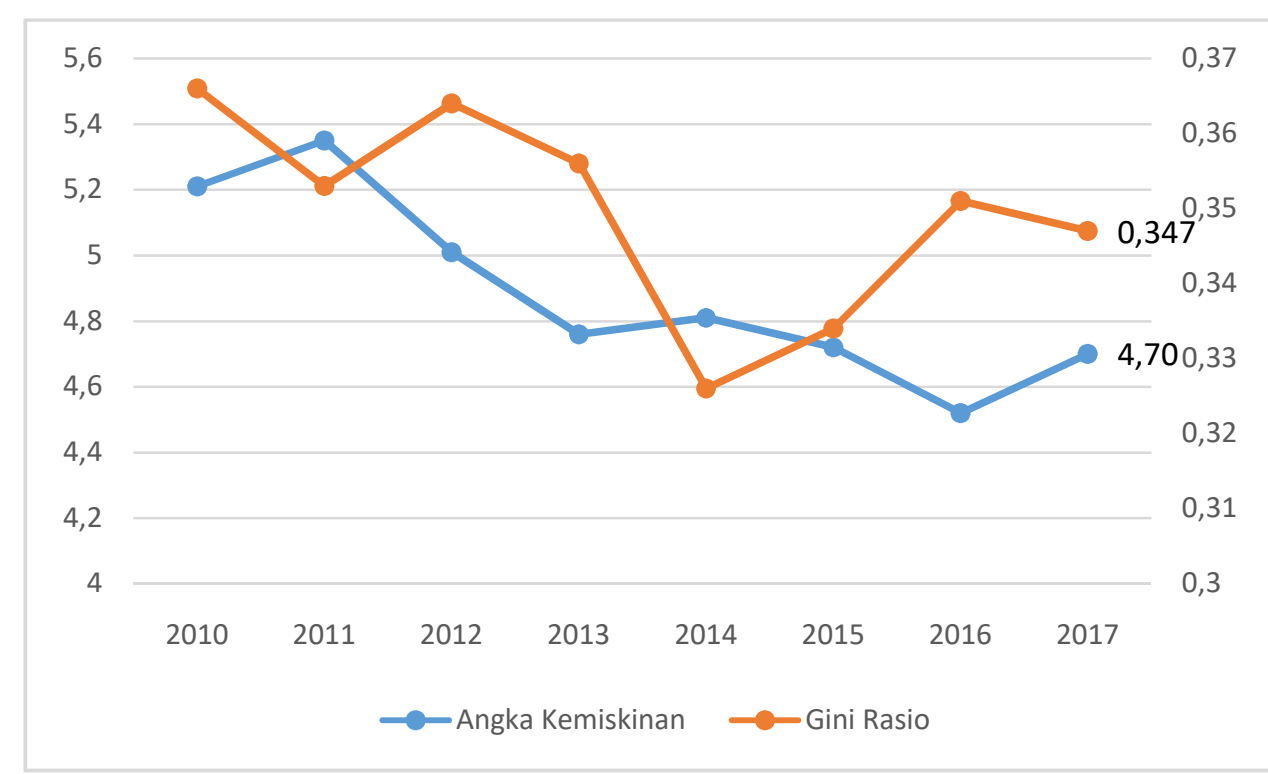

Gambar 2. Perkembangan Persentase Kemiskinan dan Gini Rasio Provinsi Kalimantan Selatan Tahun 2010-2017 (https://kalsel.bps.go.id/)

Pada tahun 2017, angka kemiskinan di Kalimantan Selatan mengalami peningkatan sekitar 0,18\% (dari 4,52\% menjadi 4,70\%). Peningkatan ini diiringi dengan ketimpangan yang tidak kunjung membaik. Ketimpangan yang ditunjukkan oleh Gini Rasio hanya turun tipis 0,004 pada tahun 2017 jika dibanding tahun 2016 (0,351 menjadi 0,347). Kondisi perekonomian Kalimantan Selatan pada tahun 2017 membaik setelah tahun 2015 mengalami titik nadir perlambatan. Namun sayangnya perbaikan kinerja perekonomian ini di topang oleh sektor yang sifatnya padat modal, dalam hal ini adalah sektor pertambangan dan penggalian. Pertumbuhan sektor yang padat modal biasanya cepat meningkatkan pertumbuhan ekonomi namun menyisakan masalah sosial yang kaya semakin kaya dan yang miskin semakin miskin yang tergambar pada ukuran Gini Rasio yang belum membaik.

Pemerintah sangat berperan penting dalam menanggulangi masalah kemiskinan. Pemerintah melalui nawa cita menjadikan investasi berupa pembangunan infrastruktur salah satu program unggulan. Infrastruktur tidak hanya dibutuhkan oleh rumah tangga tetapi juga dibutuhkan oleh dunia usaha. Apabila infrastruktur di suatu daerah memadai, daerah akan mempunyai keuntungan yang lebih besar dalam menarik investasi masuk. Hal tersebut akan menyebabkan daerah dengan infrastruktur yang memadai menjadi lebih cepat berkembang. Sehingga pembangunan infrastruktur yang dilakukan diharapkan dapat mempercepat pertumbuhan ekonomi yang akan menurunkan kemiskinan dan meningkatkan kesejahteraan. 
Published July 2019

EKONOMIKAWAN : Jurnal Ilmu Ekonomi dan Studi Pembangunan

ISSN : 1693-7600 (Print), ISSN : 2598-0157 (Online), http://jurnal.umsu.ac.ld/index.php/ekawan

Berdasarkan latar belakang di atas, maka peneliti tertarik melakukan penelitian yang berjudul "Analisis Elastisitas Investasi Terhadap Penurunan Angka Kemiskinan di Provinsi Kalimantan Selatan Tahun 2010-2017”. Permasalahan yang disampaikan dalam penelitian ini yaitu apakah gencarnya pembangunan infrastruktur (investasi) yang selama ini dilakukan efektif dan efisien terhadap penurunan kemiskinan di Provinsi Kalimantan Selatan.

\section{KAJIAN TEORI \\ Kemiskinan}

Menurut Pateda et al. (2017), "kemiskinan merupakan suatu standar hidup yang rendah atau adanya kekurangan materi pada seseorang atau sekelompok orang dibandingkan dengan standar kehidupan umum yang berlaku dalam masyarakat bersangkutan. Ditinjau dari segi ekonomi, kemiskinan didefinisikan sebagai kurangnya sumber daya yang dapat digunakan untuk memenuhi kebutuhan hidup dan meningkatkan kesejahteraan seseorang atau sekelompok orang".

Kemiskinan dapat dibedakan menjadi tiga jenis (Kuncoro, 2003):

1. Kemiskinan absolut, yaitu seseorang yang mempunyai pengeluaran perkapita dibawah garis kemiskinan. Kesulitan dalam menentukan kemiskinan absolut terletak pada menentukan garis kemiskinan atau kebutuhan minimum, karena kebutuhan minimum selain ditentukan oleh faktor ekonomi tetapi juga dipengaruhi oleh adat-istiadat.

2. Kemiskinan relatif, yaitu seseorang yang sudah dapat memenuhi kebutuhan dasarnya tetapi relatif masih lebih rendah jika dibandingkan masyarakat di sekitarnya.

3. Kemiskinan kultural, yaitu kemiskinan yang diakibatkan oleh sekelompok masyarakat yang enggan berusaha memperbaiki kehidupannya meskipun ada berbagai pihak yang berusaha untuk memperbaiki taraf hidupnya.

\section{Indikator Kemiskinan}

Bank Dunia memiliki dua kriteria dalam menentukan garis kemiskinan. Pertama, menggunakan garis kemiskinan nasional yang didasarkan pada pola konsumsi 2100 kalori per hari. Kedua, garis kemiskinan internasional berdasarkan PPP (Purchasing Power Parity) US\$1 dan US\$2. Badan Pusat Statistik (BPS) mengukur kemiskinan di Indonesia menggunakan konsep kemampuan memenuhi kebutuhan dasar (basic needs approach). Konsep ini memandang kemiskinan sebagai ketidakmampuan seseorang dari sisi ekonomi untuk memenuhi kebutuhan dasar makanan dan bukan makanan yang diukur dari sisi pengeluaran. Jadi, penduduk miskin adalah penduduk yang memiliki rata-rata pengeluaran per kapita perbulan dibawah garis kemiskinan. Garis kemiskinan (GK) merupakan penjumlahan dari Garis Kemiskinan Makanan (GKM) dan Garis Kemiskinan Non Makanan (GKNM). GKM ialah kebutuhan minimum makanan yang menggunakan ukuran 2.100 kalori per hari. Sedangkan GKNM merupakan kebutuhan minimum bukan makanan yang meliputi pengeluaran untuk perumahan, sandang, serta aneka barang dan jasa. 
Published July 2019

EKONOMIKAWAN : Jurnal Ilmu Ekonomi dan Studi Pembangunan

ISSN : 1693-7600 (Print), ISSN : 2598-0157 (Online), http://jurnal.umsu.ac.Id/index.php/ekawan

\section{Investasi}

"Investasi merupakan suatu pengeluaran yang dimaksudkan untuk meningkatkan kemampuan masyarakat sehingga dapat menigkatkan produksi. Jadi, investasi merupakan pengeluaran yang akan menambah jumlah alat-alat produksi dalam masyarakat yang akhirnya akan menambah pendapatan, sehingga pertumbuhan ekonomi meningkat. Oleh karena itu, sudah sewajarnya pemerintah melakukan kebijakan yang bertujuan untuk meningkatkan masuknya investasi" (Sutawijaya dalam Paramita \& Purbadharmaja, 2015).

Investasi memungkinkan suatu masyarakat untuk meningkatkan taraf kesejahteraannya. Hal ini diakibatkan oleh tiga fungsi penting dari investasi, yaitu (Sukirno, 2000):

1. Investasi merupakan salah satu komponen dari pengeluaran agregat, oleh karena itu kenaikan investasi akan meningkatkan permintaaan agregat, sehingga pendapatan nasioal serta kesempatan kerja akan meningkat juga,

2. Investasi akan menambah barang modal sehingga menambah kapasitas produksi,

3. Investasi selalu diikuti perkembangan teknologi.

\section{Hubungan Investasi dan Kemiskinan}

Investasi merupakan modal yang biasanya ditujukan untuk keperluan jangka panjang. Penanaman modal sangat penting untuk mengembangkan usaha baik sendiri maupun pihak lain. Penanaman modal usaha dapat berbentuk modal tetap, uang, maupun pembelian surat berharga. Investasi merupakan penghubung yang kuat untuk mempercepat pertumbuhan ekonomi dan mengurangi kemiskinan di suatu daerah (Ocaya, Ruranga, \& Kaberuka, 2012).

\section{METODE}

\section{Jenis dan Sumber Data}

Data yang diperlukan dalam penelitian ini merupakan data tahun 2010-2017 Provinsi Kalimantan Selatan, mencakup data: 1) Produk Domestik Regional Bruto (PDRB) Menurut Pengeluaran Atas Dasar Harga Konstan 2010; 2) Pembentukan Modal Tetap Bruto (PMTB) Atas Dasar Harga Konstan 2010; 3) Angka Kemiskinan. Seluruh data yang digunakan bersumber dari Badan Pusat Statistik (BPS).

\section{Metode Analisis Data}

Vietnam dan sejumlah negara lain di dunia melakukan penghitungan elastisitas investasi terhadap penurunan kemiskinan. Formula penghitungan ini dapat diaplikasikan untuk wilayah Kalimantan Selatan dengan mereplikasi apa yang sudah dilakukan oleh negara lain tersebut. Elastisitas investasi terhadap penurunan kemiskinan (e) dirumuskan sebagai berikut (Larsen, Pham, \& Rama, 2004):

$$
e=\frac{\Delta Y}{l}\left(\frac{\Delta P_{0} / P_{0}}{\Delta Y / Y}\right)
$$

Keterangan:

$\mathrm{Y} \quad=$ PDRB Atas Dasar Harga Konstan

$\Delta \mathrm{Y}=$ Selisih PDRB Atas Dasar Harga Konstan tahun $\mathrm{t}$ dengan $\mathrm{t}-1$. 
Published July 2019

EKONOMIKAWAN : Jurnal Ilmu Ekonomi dan Studi Pembangunan

ISSN : 1693-7600 (Print), ISSN : 2598-0157 (Online), http://jurnal.umsu.ac.Id/index.php/ekawan

$\mathrm{P}_{0} \quad=$ Persentase penduduk miskin

$\Delta \mathrm{P}_{0} \quad=$ Selisih persentase penduduk miskin tahun $\mathrm{t}$ dengan $\mathrm{t}-1$.

I = Jumlah Investasi/Pembentukan Modal Tetap Bruto.

\section{HASIL DAN PEMBAHASAN}

Semenjak tahun 2014, pemerintah melalui program nawa cita memiliki ambisi besar menggencarkan pembangunan infrastruktur. Hal tersebut dilakukan untuk mengejar ketertinggalan dengan negara di kawasan Asia Tenggara lainnya. Pembangunan infrastruktur menjadi keharusan ketika semua negara saling bersaing menarik investasi asing guna mengakselerasi pertumbuhan ekonomi. Infrastruktur dalam hal ini bisa diibaratkan sebagai sendi perekonomian, yang menopang arus logistik barang sebagai nadi perekonomian.

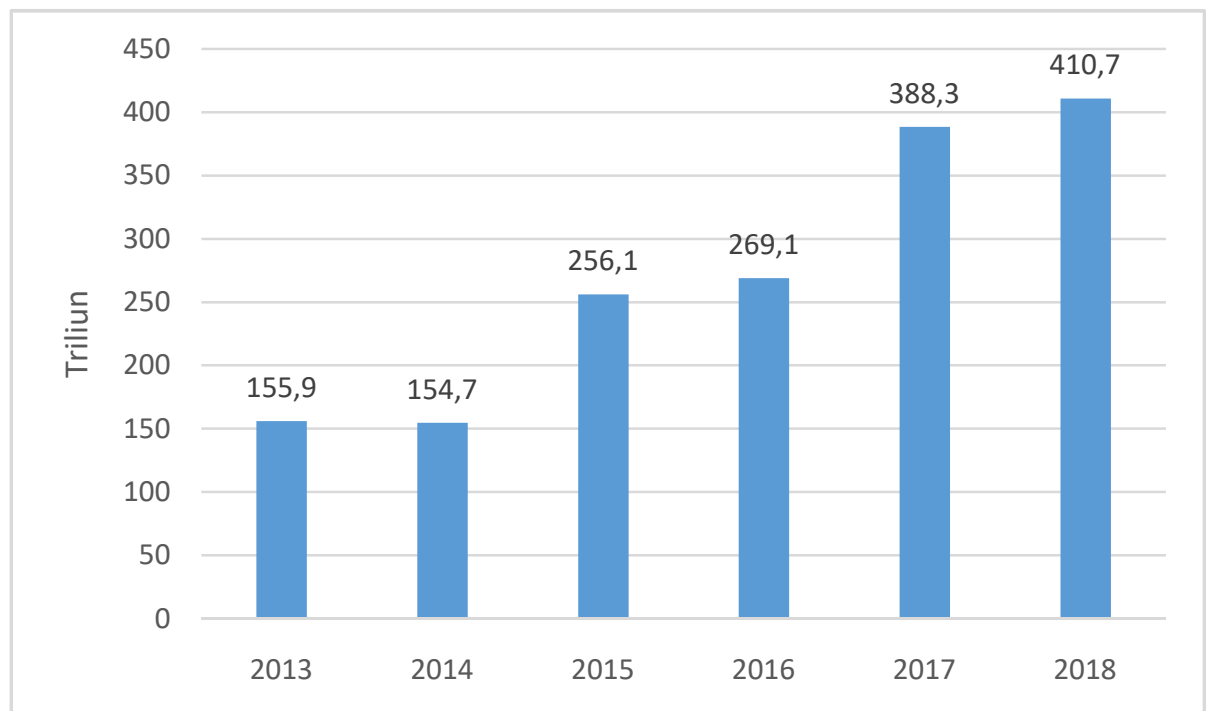

Gambar 3. Perkembangan Anggaran Infrastruktur Indonesia dalam APBN

Tahun 2013-2018 (http://visual.kemenkeu.go.id/anggaran-infrastruktur-apbn-2019/)

Gencarnya pembangunan infrastruktur ditunjukkan dengan kenaikan drastis anggaran infrastruktur dalam Anggaran Pendapatan Belanja Negara (APBN). Berdasarkan data dari Kementerian Keuangan, anggaran untuk infrastruktur yang hanya 154,7 triliun pada 2014 naik drastis menjadi 256,1 triliun pada tahun 2015. Anggaran untuk infrastruktur terus meningkat setiap tahun hingga menjadi 410,7 triliun pada tahun 2018. Pembangunan jalan raya, rel kereta, jalan tol, LRT, jembatan, menara BTS, perumahan murah, pelabuhan, dan bandara merupakan proyek-proyek yang sedang digarap pemerintah. Hal tersebut menunjukkan keseriusan pemerintah dalam menggencarkan pembangunan infrastruktur di Indonesia. 
Published July 2019

EKONOMIKAWAN : Jurnal Ilmu Ekonomi dan Studi Pembangunan

ISSN : $1693-7600$ (Print), ISSN : 2598-0157 (Online), http://jurnal.umsu.ac.Id/index.php/ekawan

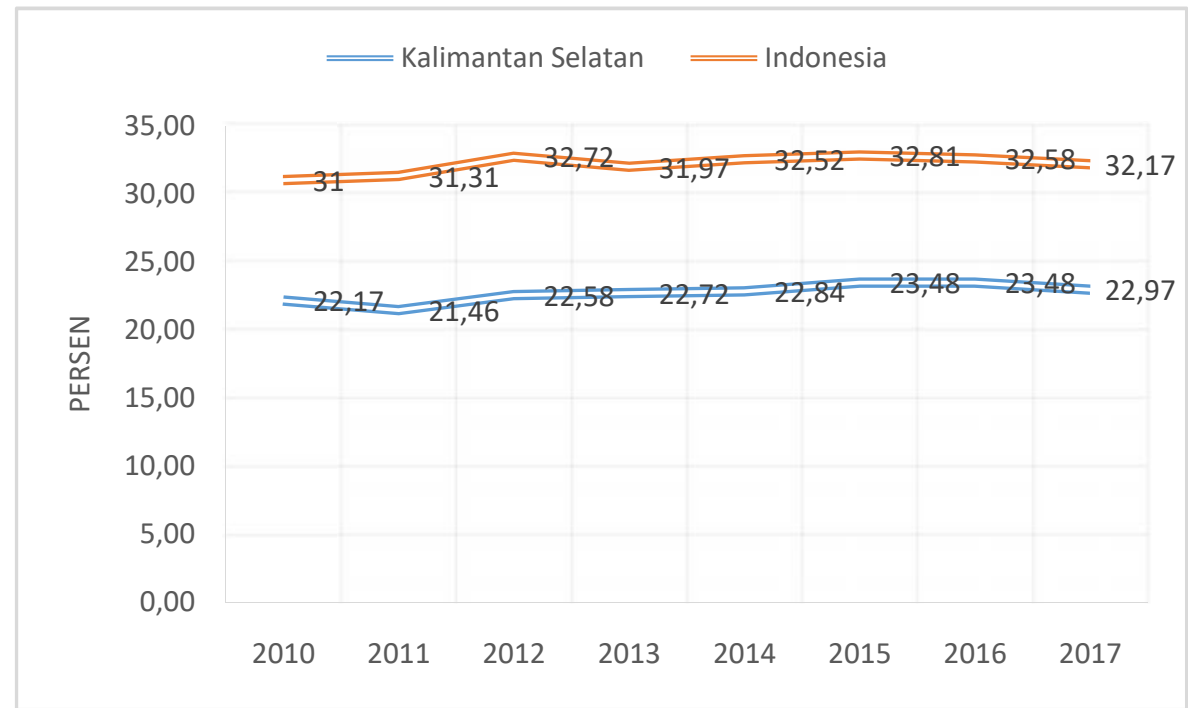

Gambar 4. Perkembangan Persentase PMTB terhadap Perekonomian

Tahun 2010-2017 (https://www.bps.go.id/)

Sejalan dengan anggaran infrastruktur yang meningkat, kontribusi PMTB terhadap PDB pun mengalami peningkatan setelah tahun 2014. Menurut data BPS, kontribusi PMTB terhadap PDB Indonesia rata-rata hanya 31,90 persen selama tahun 2010 sampai 2014. Setelah tahun 2014, kontribusi PMTB terhadap PDB Indonesia rata-rata 32,52 persen sampai tahun 2017. Provinsi Kalimantan Selatan juga mengalami hal serupa, kontribusi PMTB terhadap PDRB yang rata-rata hanya 22,35 persen selama tahun 2010 sampai 2014, meningkat menjadi rata-rata 23,31 persen setelah tahun 2014 sampai tahun 2017.

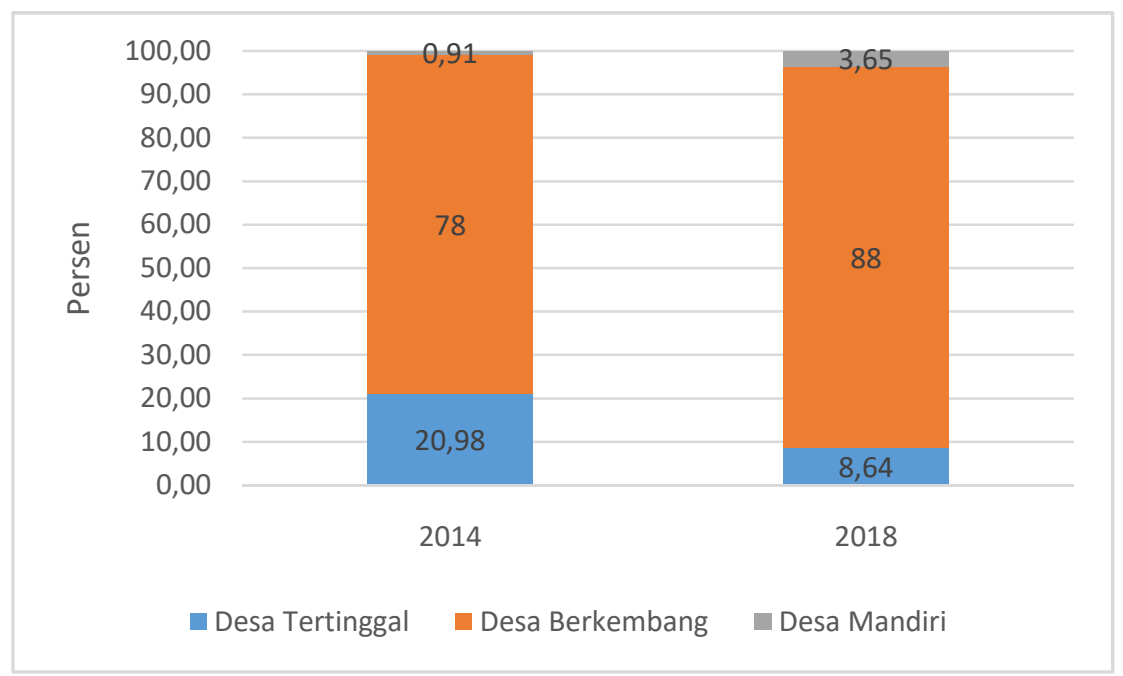

Gambar 5. Perkembangan Indeks Pembangunan Desa Provinsi Kalimantan Selatan Tahun 2014 dan 2018 (https://kalsel.bps.go.id/) 
Published July 2019

EKONOMIKAWAN : Jurnal Ilmu Ekonomi dan Studi Pembangunan

ISSN : $1693-7600$ (Print), ISSN : 2598-0157 (Online), http://jurnal.umsu.ac.Id/index.php/ekawan

Berhasil tidaknya program pemerintah dalam pembangunan salah satunya dapat tercermin dari hasil pendataan Potensi Desa (Podes). Pada tahun 2014 dan 2018, BPS melaksanakan pendataan Podes yang salah satunya menghasilkan suatu ukuran pembangunan desa yang disebut Indeks Pembangunan Desa (IPD). IPD diukur dengan menggunakan lima dimensi, yaitu kondisi infrastruktur, ketersediaan pelayanan dasar, pelayanan umum, aksesibilitas/transportasi, dan penyelenggaraan pemerintah. Indeks Pembangunan Desa (IPD) adalah indeks komposit yang menggambarkan tingkat perkembangan desa, dengan skala 0-100. Indeks Pembangunan Desa menunjukkan tingkat perkembangan desa dengan status tertinggal (kurang dari sama dengan 50), berkembang (lebih dari 50 namun kurang dari sama dengan 75), dan mandiri (lebih dari 75).

Berdasarkan Indeks Pembangunan Desa yang telah dihitung oleh BPS, menunjukkan adanya kemajuan atau perbaikan status desa di Provinsi Kalimantan Selatan. Jika dibandingkan dengan tahun 2014, Desa Tertinggal berkurang sebesar 230 desa. Sementara itu, status Desa Mandiri bertambah sebanyak 51 desa. Perbandingan status IPD ini dilakukan untuk desa-desa yang sama dengan tahun 2014, yaitu sebesar 1.864 desa.

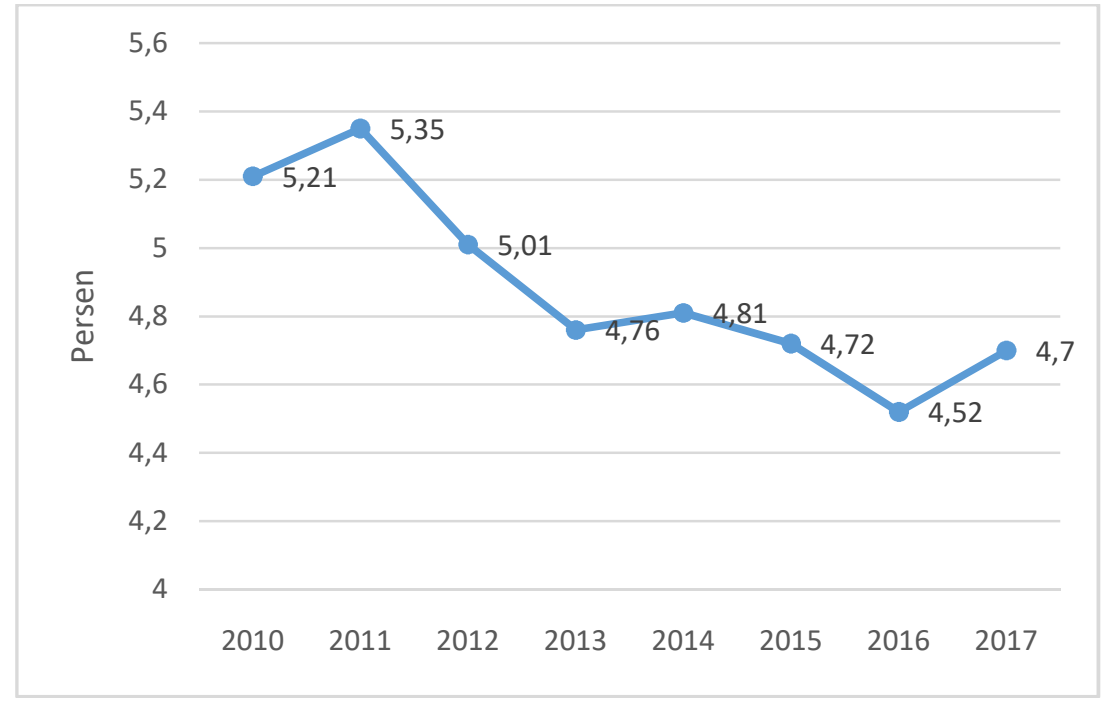

Gambar 6. Perkembangan Persentase Penduduk Miskin Provinsi Kalimantan Selatan Tahun 2010-2017 (https://kalsel.bps.go.id/)

Selain dari Indeks Pembangunan Desa (IPD), keberhasilan pembangunan infrastruktur bisa dilihat dari angka kemiskinan. Berdasarkan data BPS, angka kemiskinan Provinsi Kalimantan Selatan selama tahun 2010 sampai 2017 memiliki kecenderungan menurun. Angka kemiskinan yang mencapai 5,21 persen pada tahun 2010 turun menjadi hanya 4,7 persen pada 2017. Jika dilihat setelah tahun 2014, meskipun sempat naik menjadi 4,7 persen pada tahun 2017, secara umum angka kemiskinan mengalami tren menurun setelah tahun 2014. 
Published July 2019

EKONOMIKAWAN : Jurnal Ilmu Ekonomi dan Studi Pembangunan

ISSN : 1693-7600 (Print), ISSN : 2598-0157 (Online), http://jurnal.umsu.ac.Id/index.php/ekawan

Tabel 1. Elastisitas Investasi Terhadap Persentase Penduduk Miskin Provinsi Kalimantan Selatan Tahun 2010-2017

\begin{tabular}{|c|c|c|c|}
\hline Periode & Investment Rate & ICOR & $\mathrm{e}$ \\
\hline$(1)$ & $(2)$ & $(3)$ & $(4)$ \\
\hline $2010-2017$ & 22,71 & 4,54 & $-0,048$ \\
\hline $2010-2014$ & 22,35 & 4,05 & $-0,051$ \\
\hline $2015-2017$ & 23,68 & 5,20 & $-0,045$ \\
\hline
\end{tabular}

Sumber: Badan Pusat Statistik Provinsi Kalimantan Selatan (diolah)

Tentunya meningkatnya IPD dan juga menurunnya kemiskinan merupakan suatu keberhasilan dari gencarnya pembangunan infrastruktur oleh pemerintah. Akan tetapi, apakah infrastruktur yang gencar dibangun setelah tahun 2014 untuk menurunkan kemiskinan sudah efektif dan efisien di Kalimantan Selatan ?

Perhitungan untuk Provinsi Kalimantan Selatan memberikan informasi bahwa pada periode 2010-2014, nilai elastisitas (e) sebesar -0,051. Angka ini dapat diinterpretasikan bahwa untuk kenaikan kontribusi investasi pada PDRB sebesar 1\%, maka persentase penduduk miskin akan turun $0,051 \%$. Selanjutnya, periode 2015-2017, besaran elastisitas menjadi $-0,045$, menggambarkan bahwa untuk peningkatan kontribusi investasi pada PDRB sebesar 1\%, maka persentase penduduk miskin berkurang 0,045\%. Dari hasil perhitungan ini, dapat disimpulkan bahwa investasi yang digelontorkan sebelum maupun sesudah 2014 sudah efektif, karena sama-sama memberikan nilai elastisitas negatif terhadap kemiskinan atau dengan kata lain menurunkan angka kemiskinan. Hasil tersebut sesuai dengan penelitian dari Corong, Dacuycuy, Reyes, \& Taningco (2013) yang menyatakan bahwa "infrastruktur publik yang semakin baik akan meningkatkan rasio investasi terhadap PDB dan mengurangi kemiskinan serta ketimpangan dalam jangka pendek dan jangka panjang".

Akan tetapi, jika dilihat dari besaran elastisitasnya, setelah tahun 2014 nilai elastisitasnya lebih kecil dibanding periode sebelumnya. Hal ini menunjukkan investasi yang dilakukan kurang efisien dalam menurunkan angka kemiskinan di Kalimantan Selatan. Hal tersebut perlu menjadi perhatian untuk pemerintah bahwa meskipun efektif dapat menurunkan kemiskinan, tetapi pemerintah harus melakukan perencanaan lebih matang terkait gencarnya pembangunan infrastruktur atau terkait investasi yang telah dilakukan. Hal ini perlu dilakukan supaya infrastruktur yang telah gencar dibangun selain efektif juga efisien menggerakkan roda perekonomian yang nantinya akan menurunkan angka kemiskinan Kalimantan Selatan. Jangan sampai infrastruktur yang dibangun dengan dana yang begitu besar hanya teronggok sia-sia tidak berguna karena kurang matangnya perencanaan. 
Published July 2019

EKONOMIKAWAN : Jurnal Ilmu Ekonomi dan Studi Pembangunan

ISSN : 1693-7600 (Print), ISSN : 2598-0157 (Online), http://jurnal.umsu.ac.Id/index.php/ekawan

\section{SIMPULAN}

Semenjak tahun 2014, Pemerintah Indonesia begitu gencar dalam menambah investasi fisik melalui pembangunan infrastruktur. Persentase PMTB terhadap perekonomian pun semakin meningkat tidak terkecuali di Provinsi Kalimantan Selatan. Berdasarkan hasil penghitungan memakai rumus elastisitas, gencarnya pembangunan infrastruktur berhasil menurunkan angka kemiskinan selama tahun 2010-2017. Jika dibandingkan sebelum 2014 dan sesudah 2014, dapat disimpulkan bahwa investasi yang dilakukan sebelum maupun sesudah 2014 sudah efektif, karena sama-sama memberikan nilai elastisitas negatif terhadap kemiskinan atau dengan kata lain menurunkan angka kemiskinan. Akan tetapi, apabila dilihat dari besaran elastisitasnya, setelah tahun 2014, investasi yang dilakukan kurang efisien ditunjukkan dengan nilai elastisitas yang lebih kecil dibanding periode sebelumnya. Hal tersebut perlu menjadi perhatian untuk pemerintah bahwa meskipun investasi efektif menurunkan kemiskinan, akan tetapi pemerintah harus melakukan perencanaan lebih matang terkait gencarnya pembangunan infrastruktur atau terkait investasi yang akan dilakukan. Sehingga investasi atau infrastrukstur yang dibangun selain efektif juga efisien untuk mengurangi masalah kemiskinan di Provinsi Kalimantan Selatan.

\section{DAFTAR PUSTAKA}

Badan Pusat Statistik. (2018). Hasil Pendataan Potensi Desa (Podes) 2018 Provinsi Kalimantan Selatan. Desember. BPS Provinsi Kalimantan Selatan. Banjarbaru.

(2018). Produk Domestik Regional Bruto Menurut Pengeluaran Provinsi Kalimantan Selatan 2013-2017. Juli. BPS Provinsi Kalimantan Selatan. Banjarbaru.

Corong, E., Dacuycuy, L., Reyes, R., \& Taningco, A. (2013). The Growth and Distributive Impacts of Public Infrastructure Investments in the Philippines. Infrastructure and Economic Growth in Asia, 47-86. https://doi.org/10.1007/978-3-319-03137-8

Kolibu, M., Rumate, V. A., \& Engka, D. S. M. (2017). Pengaruh Tingkat Inflasi, Investasi, Pertumbuhan Ekonomi dan Tingkat Pengangguran Terhadap Tingkat Kemiskinan di Provinsi Sulawesi Utara. Jurnal Pembangunan Ekonomi Dan Keuangan Daerah, 19(3), 1-14.

Kuncoro, Mudrajad. (2003). Ekonomi Pembangunan Teori, Masalah dan Kebijakan. Edisi ke-3. Yogyakarta: UPP AMP YKPN.

Larsen, T. I., Pham, H. L., \& Rama, M. (2004). The Impact of Instrastructure Development on Rural Poverty Reduction in Vietnam. Scaling Up Poverty Reduction: A Global Learning Process and Conference, 1-30. Shanghai.

Mahsunah, D. (2013). Analisis Pengaruh Jumlah Penduduk, Pendidikan dan Pengangguran Terhadap Kemiskinan di Jawa Timur. Jurnal Pendidikan Ekonomi, 1(3), 1-17. 
Ocaya, B., Ruranga, C., \& Kaberuka, W. (2012). Dynamic Relationship between Gross Domestic Product and Domestic Investment in Rwanda. World Journal of Education, 2(6), 79-90. https://doi.org/10.5430/wje.v2n6p79

Paramita, A. A. I. D., \& Purbadharmaja, I. B. P. (2015). Pengaruh Investasi dan Pengangguran Terhadap Pertumbuhan Ekonomi Serta Kemiskinan di Provinsi Bali. EJurnal Ekonomi Pembangunan Universitas Udayana, 4(10), 1194-1218.

Pateda, Y., Masinambouw, V. A. J., \& Rotinsulu, T. O. (2017). Pengaruh Investasi, Pertumbuhan Ekonomi dan Pengeluaran Pemerintah Terhadap Tingkat Kemiskinan di Gorontalo. Jurnal Pembangunan Ekonomi Dan Keuangan Daerah, 19(3), 1-17.

Sukirno, Sadono. (2000). Makroekonomi Modern: Perkembangan Pemikiran Dari Klasik Hingga Keynesian Baru. Jakarta: Raja Grafindo Persada. 